\title{
THE PRESENCE OF PATHOGENIC BACTERIA IN TRADITIONAL CHEESE SOLD IN LOCAL MARKET IN HATAY PROVINCE, TURKEY
}

\author{
UNAL TURHAN, E. \\ Osmaniye Korkut Ata University, Kadirli Applied Sciences School, Food Technology \\ Department \\ TR-80760 Osmaniye, Turkey \\ (e-mail: emelunalturhan@gmail.com; phone: +90-0-328-888-0090; fax: +90-0-328-0091)
}

(Received 24 $4^{\text {th }}$ Feb 2019; accepted $11^{\text {th }}$ Apr 2019)

\begin{abstract}
Contamination of cheese by foodborne pathogens may pose a risk for human health. Especially, microbiological quality of cheese sold in local market and produced on a small scale is generally lower than industrial production. The aim of the present research was to investigate the presence of pathogenic bacteria such as coagulase positive staphylococci, Escherichia coli, Listeria monocytogenes and Salmonella spp. in twenty white cheese samples from local market on a small scale in the province of Hatay, Turkey. In this study, none of cheese samples contained L. monocytogenes and Salmonella spp. while E. coli and coagulase positive staphylococci were detected in cheese samples. The higher prevalence of coagulase positive staphylococci (100\%) than E. coli $(65 \%)$ were detected in cheese samples, but contamination levels of E. coli (mean $4.05 \log \mathrm{cfu} / \mathrm{g}$ ) were found higher that coagulase positive staphylococci (mean $2.47 \mathrm{log} \mathrm{cfu} / \mathrm{g}$ ) in terms of viable cell counts of pathogenic bacteria in cheese samples. The present results indicated that traditional cheeses manufactured in Hatay province were generally satisfactory microbiological safety according to Turkish Food Safety Criteria. As a result, the presence of pathogenic bacteria in traditional cheese from Hatay region could cause outbreaks affecting public health and reduce positive impression on traditional cheeses which have potential for geographical indication.
\end{abstract}

Keywords: small scale food producers, Turkish food codex, microbiological criteria, dairy products, contamination

\section{Introduction}

Cheese is fermented dairy product known as a safe and nutritious food with high protein and dietary calcium contents. Cheese is often consumed due to these beneficial impacts on human health, favorable sensorial and nutritional properties (Mikulec and Jovanovic, 2005; Kurşun et al., 2008; Choi et al., 2016). In Turkey, cheese is produced by both traditional methods (manual handling and unmechanized) and industrial methods (production based on mechanization). The production and consumption of domestic natural or traditional cheese in the world is rising year by year. Traditional cheeses which have distinctive taste and odor are produced on a small scale by using raw milk in mostly east, southeast region of Turkey (Hayaloğlu et al., 2002; Ozer et al., 2004; Jorgensen et al., 2005). East, south east and south of Turkey are famous for quite high summer temperatures, for example Hatay. Hatay is one of the cities where food products are frequently sold in open market places or local market on a small scale due to traditional habits (Cokal et al., 2012).

Turkish traditional white cheese is usually produced under unmechanized or artisanal conditions and is handled at various stages of manufacture. Thus, various types of microorganisms may enter the cheese during manufacture and subsequent handling (Hayaloglu et al., 2002). As a result of climate and improper hygiene conditions, white cheese producer on a small scale of Turkey often encounter with contamination risk of pathogens. In particular traditional cheese sold local market have low hygienic quality 
(Ozer et al., 2004; Başkaya et al., 2006; Uraz et al., 2008). Four bacterial pathogens including Listeria monocytogenes, Salmonella spp., Staphylococcus aureus and pathogenic Escherichia coli are the predominant microorganisms that caused outbreaks as result of contaminated traditional cheese (Motarjemi et al., 2002; Hudson et al., 2003). Salmonella spp. is gram negative gastroenteritis-inducing pathogens and the majority of Salmonella cases are foodborne (Donnelly et al., 2018). The primary source of Salmonella spp. is humans and animals as carrier (mostly their feces). Animal products are among the most common foodstuffs of Salmonella. The main foods as source of Salmonella are meat, milk and eggs and their products and also inadequately heat treated food products (Akkaya and Alişarl1, 2006). In many reports, the outbreaks of Salmonella were associated with raw milk cheese (Donnelly, 2018). Staphylococcus aureus as coagulase positive staphylococci plays an important role on human health due to the production of thermo-stable enterotoxins that causes foodborne illness. Particularly, in the dairy industry $S$. aureus is mostly pathogen as it can induce foodborne intoxications through dairy products including cheeses (Donnely, 2018). S. aureus is usually transmitted to food by personnel (hands, coughing, sneezing, etc.). Milk and milk products are the main foods that cause poisoning from S. aureus (Pacheco and Galindo, 2010). L. monocytogenes is gram positive facultative anaerobic foodborne pathogen and one of the most dangerous pathogens in food industry. It is usually found in soil, surface waters, sewage, plants, faeces and animal feed. Diseases from L. monocytogenes are more rare than others, but their effect is more severe and even fatal (Chavant et al., 2002; Pacheco and Galindo, 2010). Human listeriosis outbreaks are often associated with readyto-eat food products including cheese. Several outbreaks and sporadic cases of disease associated with the consumption of pasteurized milk, cheeses made from unpasteurized milk, and other dairy products in USA and Europe in the past decade (Esho et al., 2013). L. monocytogenes contamination was mostly found in raw milk (Esho et al., 2013). Escherichia coli is gram negative, Enterobacteriaceae family of Escherichia genus dependent, facultative anaerob, mostly moving, non-spore, rod-shaped bacteria. E. coli infection may cause foodborne diseases such as diarrhea, hemorrhagic colitis, and hemolytic uremic syndrome. According to epidemiological findings, E. coli epidemic is generally seen as a result of cucumber, carrot and lettuce consumption (Almosoud et al., 2015). E. coli are known as indicator organisms of fecal contamination during cheese processing (IDF, 2016).

Today, foodborne diseases related to cheese consumption are common problems in many countries. Microbial contamination in traditional cheese as the main potential risk factor is increasingly growing and has detrimental effects on public health (Belli et al., 2013). High pathogen risk in milk and dairy products originates from cow itself, inefficient animal health control, insufficient training of farmers, dairy raw milk used unpasteurized for the production, processing environment and employees about milk hygiene, utensils, post processing, retail process collection, transport and weakness in the cold chain during production processes and storage (Telli et al., 2012; Cokal et al., 2012; Belli et al., 2013). Especially traditional cheeses produced from raw milk (unpasteurized) pose a risk due to its pathogenic contents (Atasoy et al., 2003). Microbial safety of cheese is dependent on good manufacturing practices. Cheese producers have to comply with hygienic practices to ensure safety (Donnelly, 2018). Considering that traditional cheese is mostly made from raw milk, the application of food safety policy are essential in order to avoid microbial spoilage of milk, especially in local small scale dairy processing plants (Belli et al., 2013). The World Health Organization requires that small scale dairy 
processing plants in the developing countries urgently comply with the Codex Alimentarius principles (WHO, 2007). Hazard Analysis of Critical Control Points (HACCP) and Good Manufacturing Practices (GMP) are also recommended for the small production units (Belli et al., 2013).

There are limited studies based on microbial safety of traditional cheese in the province of Hatay. The present study was aimed to evaluate hygienic quality and safety of traditional cheese from local market on a small scale in Hatay province, Turkey.

\section{Material and Methods}

\section{Samples and indicator microorganisms}

In this study, totally 20 cheese samples were collected from small scaled local market in Hatay province, Turkey (Figure 1 and Figure 2). For all identification tests, pathogenic bacteria including Escherichia coli ATCC-35150, Salmonella spp., Listeriamonocytogenes ATCC7644 (Remel-USA) and Staphylococcus aureus ATCC-25923 was used as indicator organisms for the aim of positive control. Pathogen bacteria were grown in BHI (Merck, Germany) and stocked at $-20^{\circ} \mathrm{C}$ in $\mathrm{BHI}$ supplemented with $20 \%$ (v/v) glycerol.
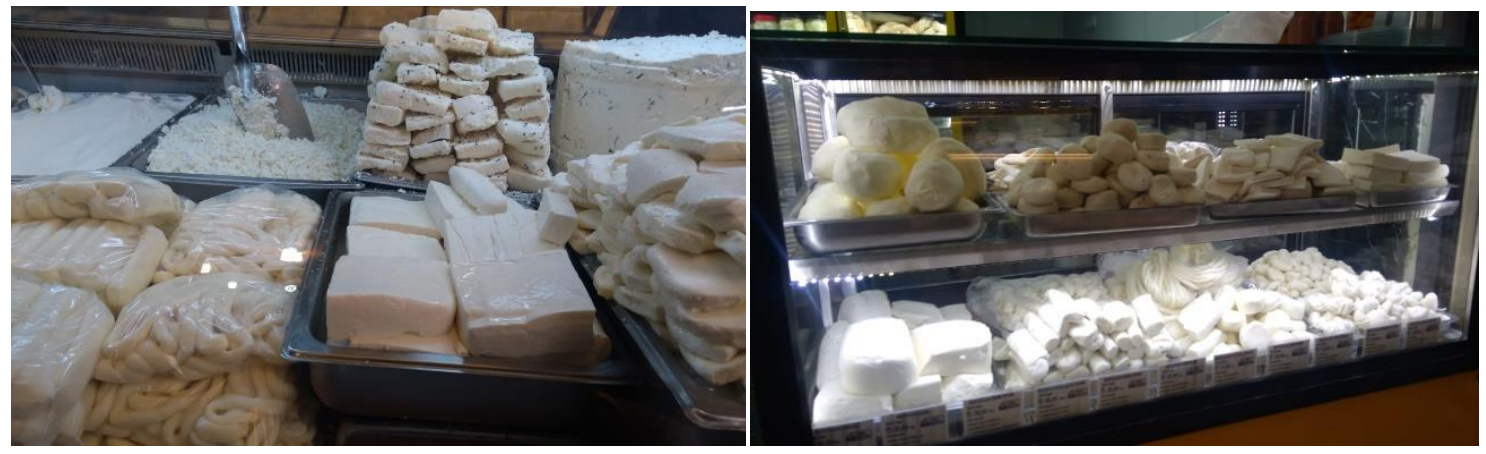

Figure 1. Traditional cheese collected from local market on a small scale in Hatay province

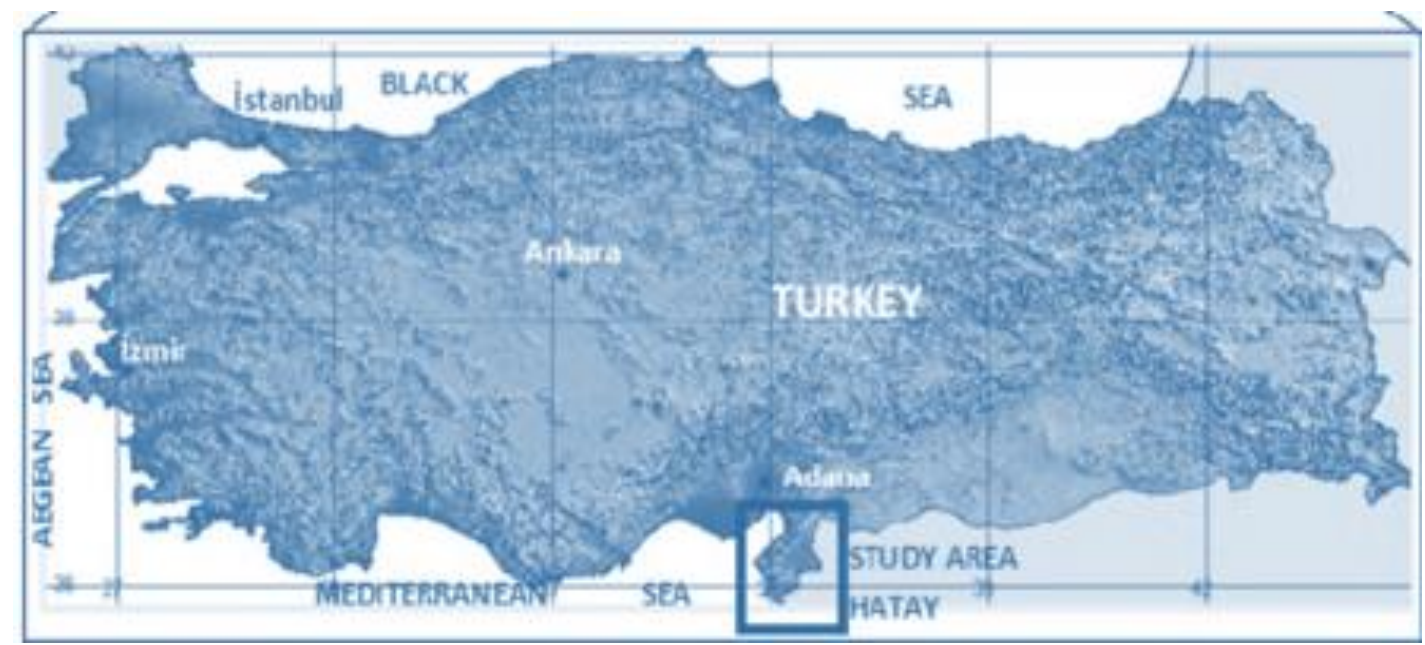

Figure 2. Hatay province of Turkey (Demirkesen, 2012) 


\section{The preparation of samples for microbiological analysis}

The homogenates of cheese samples were prepared by aseptically removing $25 \mathrm{~g}$ of cheese into sterile filter-stomaching bags (Isolab). A $225 \mathrm{~mL}$ of buffered peptone water was also added into the stomaching bags containing the samples and homogeneously mixed in stomacher (Bagmixer-interscience, France) twice for $1 \mathrm{~min}$. The sample homogenates were serially diluted with buffered peptone water.

\section{Isolation and enumeration of microorganisms}

The isolation of pathogenic bacteria in cheese samples was performed according to the reference methods of EN/ISO 6888 for coagulase positive staphylococci, EN/ISO 112901 for L. monocytogenes and EN/ISO 6579 for Salmonella spp. and EN/ISO 16649 for E.coli (Halkman, 2005; Turkish Food Codex, 2011).

For E. coli enumeration, decimal serial dilutions of the homogenate were plated in duplicate on TBX agar (Merck) plates. After incubation of plates at $44^{\circ} \mathrm{C}$ for $18-24$ hours, the blue green colonies were counted as E. coli.

For coagulase positive staphylococci ( $S$. aureus and other species) enumeration, decimal serial dilutions of the homogenate were plated in duplicate on Baird parker-RPF agar (Oxoid) plates. After at $37^{\circ} \mathrm{C}$, for 24 hours, typical black and bright colonies were counted as coagulase positive staphylococci.

For the isolation of Salmonella spp., homogenate of cheese samples in erlenmeyer flask were incubated at $35-37^{\circ} \mathrm{C}$ for $16-20$ hours. Then, $10 \mathrm{~mL}$ homogenate were added to RVS broth (Oxoid) as selective pre-enrichment medium and incubated at $42-43^{\circ} \mathrm{C}$ for 24 hours. Afterthat, inocula from the pre-enrichment medium were streaked in duplicate onto Brilliant Green agar plates (Oxoid). After incubation of plates at $37^{\circ} \mathrm{C}$ for 24 hours, typical Salmonella colonies reproduced or not on the selective agar plates.

For the isolation of L. monocytogenes, $25 \mathrm{~g}$ of each sample was taken aseptically and homogenized in $225 \mathrm{~mL}$ Fraser broth (Oxoid) using a stochmacher (Bagmixer-interscience, France) for $1 \mathrm{~min}$ and incubated at $30^{\circ} \mathrm{C}$ for 48 hours. Then, inocula from the enrichment culture were streaked in duplicate onto each of two selective agars, Oxford agar (Oxoid) and PALCAM agar (Oxoid). After incubation of both selective plates at $35-37^{\circ} \mathrm{C}$ for $48 \mathrm{~h}$, typical Listeria colonies reproduced or not on the selective agar plates.

\section{Results}

To asses microbiological safety of traditional cheese in Hatay province, a total of 20 cheese samples were collected from local market on a small scale in Hatay. Table 1 represented the presence of pathogenic bacteria in traditional cheese samples from local markets on a small scale in Hatay. Additionally, viable cell counts of these pathogens which are present in these cheese were given in Figure 3. In this study, while E. coli $(n=13)$ and coagulase positive staphyloccoci $(n=20)$ were isolated in cheese samples, Salmonella spp. and L. monocytogenes were not isolated from any cheese samples. $45 \%$ of coagulase postive staphylococci exceeded the acceptable levels in Turkish Food Safety Criteria. However, since the Turkish Food Safety Criteria does not include any limitation on the number of E. coli that is allowed to be present in the white cheese, no comment could be made for E.coli levels in the present study. 
Table 1. The presence of pathogenic bacteria in cheese from milk

\begin{tabular}{c|c|c|c|c|c|c}
\hline Microorganism & n & m & $\begin{array}{c}\text { Mean } \\
(\log \mathbf{c f u} / \mathbf{g})\end{array}$ & Std. Dev & $\begin{array}{c}\text { Max } \\
(\log \mathbf{c f u} / \mathbf{g})\end{array}$ & $\begin{array}{c}\text { Min } \\
(\mathbf{l o g} \mathbf{~ c f u} / \mathbf{g})\end{array}$ \\
\hline E. coli & 13 & $\mathrm{UD}$ & 4.05 & 1.03 & 5.67 & 1.91 \\
Coagulase positive staphylococci & 20 & 9 & 2.47 & 1.32 & 4.69 & 1 \\
L. monocytogenes & $\mathrm{NF}$ & $\mathrm{NF}$ & $\mathrm{NF}$ & $\mathrm{NF}$ & $\mathrm{NF}$ & $\mathrm{NF}$ \\
Salmonella spp. & $\mathrm{NF}$ & $\mathrm{NF}$ & $\mathrm{NF}$ & $\mathrm{NF}$ & $\mathrm{NF}$ & $\mathrm{NF}$ \\
\hline
\end{tabular}

$\mathrm{n}$ : The number of samples containing pathogens, m: The number of samples containing pathogens at unaccaptable level according to Turkish Food Safety criteria, NF: not found, UD: undefined in Turkish Food Safety criteria for white cheese samples

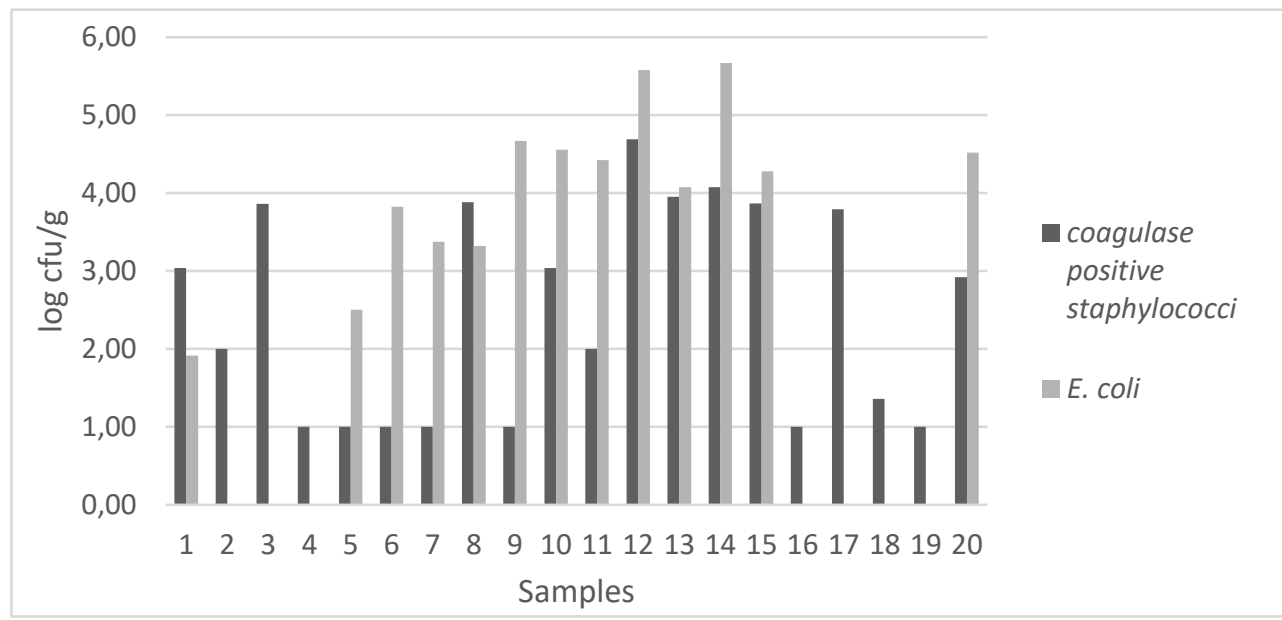

Figure 3. Viable cell counts of pathogens which are present in traditional cheese

\section{Discussion}

Farmhouse or small scale production of traditional cheeses was associated with higher microbiological risk. Food safety was seen as a critical factor in the production of such cheese types. Various small-scale production of raw milk products has performed in the world (Obrien et al., 2009). However, there is some concern that such foods may pose a risk of pathogenic bacterial food poisoning to consumers (Jorgensen et al., 2005). Similarly, in Turkey traditional cheeses were obtained with small scale production and sold in local markets. Traditional handmade cheese in Hatay, mostly reach to local market without retaining ripening duration or without providing cold chain. Thus, these cheeses are susceptible to the development of pathogenic bacteria.

In brief, as known, cheese produced with unpasteurized milk may result in foodborne outbreaks. On this sense, food industry which purposes microbiological safety prefers the use of pasteurized milk for the production of cheese. However, sensorial properties of cheeses from unpasteurized milk and pasteurized milk are different from each other and according to consumer demands both type cheese were also sold on the market. Therefore the achievement of microbiological safety in traditional cheese is essential during processing including manual handling, molding and ripening. Additionally, concentration of brine solution, storage conditions, ingredients, cheese composition and packaging etc. play an important role on microbial charge of cheese. The safety of traditional cheese 
could particularly ensure with microbial risk assessments based on ripening duration, water activity and storage conditions (Choi et al., 2016).

L. monocytogenes, S. aureus, E. coli and Salmonella spp. are well-recognized foodborne bacterial pathogens. Traditional cheese from raw milk could support the growth of such foodborne pathogens. Therefore, there is concern for microbiological safety of domestically produced traditional cheeses (Esho et al., 2013). If pathogens are present in raw milk, they can be present throughout a cheese. Raw milk or contaminated milk was seen as the source of L. monocytogenes, however the primary route of Listeria contamination of dairy products results from environmental contamination during processing (Donnelly, 2018). Various reports detected its presence in milk and cheese (Akkaya and Alişarlı, 2006). In addition to this, traditional cheeses are at risk of containing pathogenic bacteria due to post-processing contamination that can occur during manufacture, as well as during ripening and washing, or at retail (Donnelly, 2018). The incidence of high $E$. coli and $S$. aureus count in food is considered as indicator for poor hygienic condition in production process (Obrien et al., 2009; Samouris et al., 2011; Esho et al., 2013).

The result of this study showed that $65 \%$ and $100 \%$ of cheese samples contains $E$. coli and coagulase positive staphylococci, respectively. The presence of $E$. coli and coagulase positive staphylococci showed that microbiological quality of traditional white cheese samples was generally poor because of inadequate hygienic conditions during production (Hayaloğlu et al., 2002; Ozer et al., 2004; Telli et al., 2012; Belli et al., 2013). In general while the presence of $S$. aureus, L. monocytogenes and Salmonella spp. in cheese stemmed from raw milk, the presence of $E$. coli associated with inappropriate or hygienic conditions (Torkar et al., 2006; Obrien et al., 2009; Pacheco and Galindo, 2010; Yücel and An1l, 2011). According to microbiological criteria linked to food safety policy in Turkey, while the presence of L. monocytogenes and Salmonella spp. are not allowed in cheese, the presence of coagulase positive staphylococci are limited between 2 and $3 \log$ cfu/g (Turkish Food Codex, 2011). Similarly, microbiological criteria prepared by European commission associated with food safety and hygiene referred the same limits with regard to L. monocytogenes, Salmonella spp. and coagulase positive staphylococci in cheese. Our results about the presence of L. monocytogenes and Salmonella spp. in cheese samples comply with microbiological criteria. However, the amount of coagulase positive staphylococci isolated from some cheese samples used in this study has exceed the limit values. As seen in Figure 3, higher amounts of coagulase positive staphylococci than microbiological criteria were found as 4.69 and $4.68 \mathrm{log} \mathrm{cfu} / \mathrm{g}$ in samples 12 and 14. Although microbiological criteria for L. monocytogenes, Salmonella spp. and coagulase positive staphylococci in cheese are described by Turkish Food Safety criteria and European Commission microbiological criteria, E. coli are not specified. In case of using unpasteurized raw milk, producers must process products under equivalent temperature condition $\left(63^{\circ} \mathrm{C}\right.$ for $\left.30 \mathrm{~min}\right)$ to eliminate the risk of pathogenic bacteria. Thus, E. coli are not expected to exist due to the heating process in the production of traditional cheese. Additionally, postproduction contamination, poor hygienic practices and equipment are the challenging factors in cheese-related foodborne illness (Esho et al., 2013). As shown in Table 1, traditional white cheese in Hatay province contained detectable numbers of coagulase positive staphylococci between 1 and $4.69 \mathrm{log}$ cfu/g and E. coli between 1.91 and $5.67 \mathrm{log} \mathrm{cfu} / \mathrm{g}$. Similar to our results, according to the previous reports based on Turkish traditional white cheese, E. coli and S. aureus amounts in white cheese were between 0.60-5.15 log cfu/g and 1.30-1.70 log cfu/g, respectively, whereas Salmonella 
spp. and L. monocytogenes were generally not present from the cheese samples (Hayaloğlu et al., 2002).

The presence of Staphylococcus aureus, Salmonella spp. and L. monocytogenes were mostly found during the cheese making process in small-scale raw milk cheese production. The main reason for such contamination is considered as the use of raw milk (Jorgensen et al., 2005; Kaynar et al., 2005; Jakobsen et al., 2011; Esho et al., 2013; Rola et al., 2016). E. coli are one of indicators of fecal contamination during cheese processing. Especially, cheese produced from unpasteurised milk (raw) can contain E.coli. Because $E$. coli is seen as a hygiene indicator for raw milk cheese, a manufacturer need to attempt to implement an appropriate HACCP plan. (Samouris et al., 2011; IDF, 2016). E. coli and $S$. aureus are the dominant pathogenic microflora in traditional cheese (Ozer et al., 2004). Previous studies were usually referred $E$. coli and $S$. aureus as the main contamination sources of cheeses whereas contamination of cheese by Salmonella spp. and L. monocytogenes stated as very few or none (Torkar et al., 2006; Obiren et al., 2009; Pacheco and Galindo, 2010). The presence of L. monocytogenes and Salmonella spp. in traditional cheese samples was highly rare and generally at rate of between 1and 3\% or none (Kara, 1999; Kaynar et al., 2005; Torkar at al., 2006; Keskin et al., 2006; Jakobsen et al., 2011; Telli et al., 2012; Esho et al, 2013). The present results confirmed this literature information.

$S$. aureus is common in milk and milk products and could cause intoxications with its toxins during processing (Ünlütürk, 2003). In international literature information, coagulase positive staphylococci were isolated on farms with small scale production of saw milk cheeses in Poland and their concentrations were ranged from approximately 0.5 to $7.5 \mathrm{log} \mathrm{cfu} / \mathrm{g}$ (Rola et al., 2016). For example, Jorgensen et al. (2005) detected the presence of $S$. aureus in raw milk cheese with small scale production at levels of $3 \mathrm{log}$ $\mathrm{cfu} / \mathrm{g}$. On the other hand, E. coli amounts of cheese made with raw milk were ranged from 0.46 to $5.38 \log \mathrm{cfu} / \mathrm{g}$ (Samouris et al., 2011).

In previous studies based on microbiological quality of white cheese in Turkey, the presence of $S$. aureus and E. coli were found about between $40 \%$ and $100 \%$ and their amounts were varied from 1 and $6 \mathrm{log} \mathrm{cfu} / \mathrm{g}$. For instance, Torkar et al. (2006) investigated the occurrence of pathogenic bacteria in cheese produced at small dairy processing plants. Accordingly, all tested samples contained coagulase staphylococci (approximately $4 \mathrm{log} \mathrm{cfu} / \mathrm{g}$ ) and $E$. coli (approximately $6 \mathrm{log} \mathrm{cfu} / \mathrm{g}$ ) whereas Salmonella spp. and L. monocytogenes were not detected. Ozer et al (2004) reported that at the end of the 90-day storage period (at different brine concentration) in white Urfa cheese samples, $S$. aureus and E. coli were respectively found at level of between 3 and $4 \log \mathrm{cfu} / \mathrm{g}$ and 0 and $3.5 \mathrm{log} \mathrm{cfu} / \mathrm{g}$ however, Salmonella spp. could not detected. As seen, up to 90 days $S$. aureus and $E$. coli protected their viability. Our result also supported the hypothesis that the presence of E. coli and coagulase positive staphlococci in traditional cheese produced from raw milk in local market is possible. Additionally, Cokal et al (2012) reported that while contamination levels of L. monocytogenes, E. coli and S. aureus in Turkish traditional cheese samples were found 5\%, 43\% and $100 \%$, respectively, none of food samples contained Salmonella spp. In accordance with this, the highest pathogen contamination arisen from coagulase positive staphylococci and followed E. coli. In the present study none of 20 samples had the presence of $L$. monocytogenes and Salmonella spp., however it does not mean that L. monocytogenes is not present in the whole cheese samples sold in Hatay. If more cheese samples were collected in Hatay, the prediction of pathogen contamination levels could be increased. 
Keskin et al. (2006) investigated microbiological quality of the white cheese sold on street markets. The presence of $86 \% \mathrm{E}$. coli and $66 \% \mathrm{~S}$. aureus were detected and were not present Salmonella spp. and L. monocytogenes. Başkaya et al. (2006) determined approximately $2 \log \mathrm{cfu} / \mathrm{g}$ E. coli and $S$. aureus in civil cheese (another Turkish traditional cheese). Bilge and Karaboz (2005) detected the presence of Staphylococcus aureus (about 2-3 $\log \mathrm{cfu} /$ ) in some white cheese marketed in Izmir. Our results are in accordance with these previous reports.

To improve the food safety in small-scale cheese production, producers should be increasingly aware of the importance of some pre-requisites and process control points. As process control in cheese production, producers could focus on the quality of milk, regular cleaning of equipment and facilities, optimal concentrations of brine and processing factors such as time, $\mathrm{pH}$ and temperature. To reveal strengths and weaknesses of small scale cheese production, survey including questions such as personnel, education, dairy premises, utensils, production volume, hygiene barriers, control measures, water supply, pasteurization conditions and procedures for handling starter cultures should be implemented to producers (Rosengren et al., 2012; Damico et al., 2017). For example, by food safety authority of Ireland, a workbook has been produced to assist farmhouse cheesemakers meet their legal obligation to develop and implement a food safety management system based on the principles of HACCP (Hazard Analysis and Critical Control Point), also referred to as HACCP-based procedures. This workbook provides a controlled approach by describing and recording each step during individual operations in cheesemaking, from raw material production/purchasing through to the storage and dispatch of cheese (Food Safety Authority of Ireland, 2019). On this sense, small scale cheese producers need to develop and implement HACCP plan based on their specific productions (Zhao et al., 2003; Hof et al., 2008). HACCP system as one of the most important systems in quality assurance programs is a plant-specific and productspecific quality system. The application of HACCP plan in small-scale cheese plant could ensure the food safety via the identification of microbiological hazards (Nasr et al., 2017).

\section{Conclusion}

The present study concluded that the microbiological quality and hygienic status of traditional cheese analyzed in this study were mainly favorable. Most of traditional cheese samples analyzed in this paper complied with the microbiological criteria notifications on food safety by Turkish government. In Turkey, cheese is automatically produced in industrial plants with large food factories or traditionally on a small scale in local markets. Handmade cheeses with raw milk could have deficiencies from utensils, staff and other unstable processing conditions in terms of hygienic quality. In particular, raw milk constitutes the critical control point in the production process of traditional cheeses. Pathogen risk is inevitable in cheeses manufactured from low microbial quality milk. As a matter of fact such contaminated cheese could result in the outbreaks of foodborne pathogens including L. monocytogenes, Salmonella spp., E. coli and S. aureus. Policies on food safety and protection have focused on ensuring food safety in conventional products. On this sense, for the sustainability of traditional cheeses, microbial safety must be ensured with a HACCP or other food safety plan in manufacturing field and producers should focus on the hygienic conditions during milking and cheese processing. 


\section{REFERENCES}

[1] Akkaya, L., Alişarlı, M. (2006): Afyonkarahisar'da tüketime sunulan peynirlerde Listeria monocytogenes ve Salmonella spp. varlığının belirlenmesi (An investigation on the presence of Listeria monocytogenes and Salmonella spp. in retail cheeses consumed in Afyonkarahisar province, Turkey). - YYÜ Vet Fak Derg 17(1-2): 87-91.

[2] Almasoud, A., Hettiarachchy, N., Rayaprolu, S., Horax, R., Eswaranandam, S. (2015): Electrostatic spraying of organic acids on biofilms formed by E. coli $\mathrm{O} 157: \mathrm{H} 7$ and Salmonella Typhimurium on fresh produce. - Food Research International 78: 27-33.

[3] Atasoy, F. E., Türkoğlu, H., Ozer, B. H. (2003): Şanlıurfa ilinde üretilen ve satışa sunulan süt, yoğurt ve urfa peynirlerinin bazı mikrobiyolojik özelikleri (Some microbiological properties of raw milk, yogurt and fresh Urfa cheese produced and sold in Sanliurfa province). - J. Agric Fac. HR. U. 7(3-4): 77-83.

[4] Başkaya, R., Atasever, M., Çakmak, Ö., Yıldız, A. (2006): Civil peynirinin mikrobiyolojik nitelikleri (Microbiological properties of civil cheese). - J Fac. Vet. Med. istanbul Univ. 32(2): 87-94.

[5] Belli, P., Cantafora, A. F. A., Stella, S., Barbieri, S., Crimella, C. (2013): Microbiological survey of milk and dairy products from a small scale dairy processing unit in Maroua (Cameroon). - Food Control 32: 366-370.

[6] Bilge, F., Karaboz, İ. (2005): İzmir'de piyasada açıkta satışa sunulan bazı gıdaların Staphylococcus aureus ve enterotoksinleri bakımından incelenmesi (Investigation of some foodstuffs marketed in Izmir in terms of Staphylococcus aureus and enterotoxins). - Orlab On-Line Mikrobiyoloji Dergisi 3(6): 1-6.

[7] Chavant, P., Martinie, B., Meylheuc, T., Fontaine, M. N. B., Hebraud, M. (2002): Listeria monocytogenes LO28: Surface physicochemical properties and ability to form biofilms at different temperatures and growth phases. - Applied and Environmental Microbiology 68(2): 728-737.

[8] Choi, K. H., Lee, H., Lee, S., Kim, S., Yoon, Y. (2016): Cheese microbial risk assessments - a review. - Asian Australas. J. Anim. Sci. 29(3): 307-314.

[9] Cokal, Y., Dagdelen, A., Cenet, O., Gunsen, U. (2012): Presenceof L. monocytogenes and some bacterial pathogens in two Turkish traditional foods, Mihalic cheese and Hosmerim dessert. - Food Control 26: 337-340.

[10] Damico, D. J. (2017): Recommendations and outcomes from the first artisan cheese food safety forum. - Food Protection Trends 37(5): 332-339.

[11] Demirkesen, A. C. (2012): Multi-risk interpretation of natural hazards for settlements of the Hatay province in the east Mediterranean region, Turkey using SRTM DEM. Environmental Earth Sciences 65(6): 1-13.

[12] Donnelly, C. (2018): Review of controls for pathogen risks in scottish artisan cheeses made from unpasteurised milk. - Food Standards Scotland 134p.

[13] Esho, F. K., Enkhtuya, B., Kusumota, A., Kawamoto, K. (2013): Microbial assesment and prevelance of foodborne pathogens in natural cheeses in Japan. - Hindawi Publishing Corporation, Biomed Research International 6p.

[14] Food Safety Authority of Ireland. (2019): HACCP/Food safety workbook for farmhouse cheesemakers. - https://www.fsai.ie.

[15] Halkman, K. (2005): Merck Gida Mikrobiyolojisi Uygulamaları (Merck Food Microbiology Practices). - Başak Matbaacılık Limited Şti., Ankara, Türkiye, 358s.

[16] Hayaloğlu, A. A., Guven, M., Fox, P. F. (2002): Microbiological, biochemical and technological properties of Turkish White cheese 'Beyaz Peynir'. - International Dairy Journal 12: 635-648.

[17] Hofi, M. E., Tanboly, E. S. E., Ismail, A. (2008): Implementation of the hazard analysis critical control point (haccp) system to uf white cheese production line. - Internet Journal of Food Safety 10: 1-8. 
[18] Hudson, A., Wong, T., Lake, R. (2003): Pasteurisation of dairy products: times, temperatures and evidence for control of pathogens. - Institute of Environmental Science $\&$ Research Limited, Christchurch Science Centre, Food Saftey Authority 55p.

[19] IDF Factsheet. (2016): International dairy federation. - www.fil.idf.org.

[20] Jakobsen, R. A., Heggebo, R., Sunde, E. B., Skjervheim, M. (2011): Staphylococcus aureus and Listeria monocytogenes in Norwegian raw milk cheese production. - Food Microbiology 28: 492-496.

[21] Jorgensen, H. J., Mork, T., Rorvik, L. M. (2005): The occurrence of Staphylococcus aureus on a farm with small-scale production of raw milk cheese. - J. Dairy Sci. 88: 3810-3817.

[22] Kara, A. A. (1999): Erzurum piyasasından temin edilen beyaz ve civil peynirlerden, Listeria türlerinin izolasyon ve identifikasyonu (Investigation on the isolation and identification of the Listeria species in the white and civil cheeses purchased from Erzurum region). - Tr. J. of Biology 23: 331-337.

[23] Kaynar, Z., Kaynar, P., Koçak, C. (2005): Ankara piyasasinda tüketime sunulan beyaz peynirlerin hijyenik kalitelerinin belirlenmesi üzerine bir araştirma (A research on hygienic quality of pickled white cheeses in Ankara market). - Türk Hij Den Biyol Der 62: 1-10.

[24] Keskin, Y., Özyaral, O., Başkaya, R., Susur, M. A. (2006): Investigation of microbiological quality of the white cheese sold on street markets. - Türk Mikrobiyol Cem Derg 36(1): 919.

[25] Kurşun, Ö., Kırdar, S. S., Kale, A. S. A., Güner, A. (2008): Burdur'da tüketime sunulan beyaz salamura peynirlerin mikrobiyolojik kalitesinin belirlenmesi (The determination of microbiological quality of white brine cheese consumed in Burdur). - Türkiye 10. Gida Kongresi, 21-23 Mayıs Erzurum, 817-820.

[26] Mikulec, D. P., Jovanovic, L. (2005): Microbiological study of fresh white cheese (a serbian craft variety). - Applied Ecology and Environmental Research 4(1): 129-134.

[27] Motarjemi, Y. (2002): Impact of small scale fermentation technology on food safety in developing countries. - International Journal of Food Microbiology 75: 213-229.

[28] Nasr, N. F., Gizawy, S. E., Zahra, M. K. (2017): Application of quality assurance programs in small dairy plants. - Journal of Nutritional Health \& Food Engineering 7(1): 214-220.

[29] Obrien, M., Hunt, K., McSweeney, S., Jordan, K. (2009): Occurrence of food borne pathogens in Irish farm house cheese. - Food Microbiology 26: 910-914.

[30] Ozer, H. B., Uraz, G., Yilmaz, E. B., Atasoy, A. F. (2004): The effects of brine concentration and scalding on survival of some pathogens in urfa cheese: a traditional white-brined turkish cheese. - International Journal of Food Science and Technology -39: 727-735.

[31] Pacheco, F. P., Galindo, A. B. (2010): Microbial safety of raw milk cheeses traditionally made at a $\mathrm{pH}$ below 4.7 and with other hurdles limiting pathogens growth. - In: Mendez Vilas, A. (ed.) FORMATEX, Current Research, technology and Education Topics in Applied Microbiology and Microbial Biotechnology, p: 1205-1216.

[32] Rola, J. G., Czubkowska, A., Dzirba, W. K., Osek, J. (2016): Occurrence of Staphylococcus aureus on farms with small scale production of raw milk cheeses in Poland. - Toxins 8(62): $1-9$.

[33] Rosengren, A. (2012): Microbiological food safety of cheese produced in swedish smallscale dairies. - Swedish University of Agricultural Sciences, Faculty of Natural Resources and Agricultural Sciences, Department of Microbiology, Uppsala, Licentiate Thesis, 60p.

[34] Samouris, G., Zdragas, A., Vafeas, G., Belibasaki, S. (2011): Survival of pathogens in "Graviera Kritis" cheese made with raw and pasteurized milk. - Journal of the Hellenic Veterinary Medical Society 62(3): 205-21.

[35] Telli, N. (2012): Listeria monocytogenes'in salamura beyaz peynir üretim hattinda kontaminasyon kaynaklarinin belirlenmesi ve PFGE metodu ile genotiplendirilmesi (Detection of contamination sources of Listeria monocytogenes in pickled white cheese production process line and genotyping with PFGE method). - Selçuk Üniversitesi Sağlik Bilimleri Enstitüsü (Selcuk University Health Sciences Institue), Besin Hijyeni ve 
Teknolojisi Anabilim Dalı (Food hygiene and technology department), Doktora Tezi ( $\mathrm{PhD}$ Thesis), 120p.

[36] Torkar, K. G., Teger, S. G. (2006): The presence of some pathogen micro organisms, yeasts and moulds in cheese samples produced at small dairy-processing plants. - Acta agriculturae Slovenica 88(1): 37-51.

[37] Turkish Food Codex. (2011): Mikrobiyolojik Kriterler Tebliği (Communiqué on microbiological criteria). - Ek-1:Gıda Güvenilirliği Kriterleri (Annex-1: Food safety criteria), $17 \mathrm{p}$.

[38] Uraz, G., Coşkun, S., Ozer, B. (2008): Microflora and pathogen bacteria (Salmonella, Klebsiella, Yersinia, Pseudomonas, Aeromonas, Esherichia coli, Staphylococcus aureus) in Urfa cheese (a traditional white brined turkish cheese). - Pakistan Journal of Nutrition 7(5): 630-635.

[39] Ünlütürk, A. (2003): Süt ve süt ürünlerinde mikrobiyolojik bozulmalar ve muhafaza yöntemleri (Microbiological spoilage and preservation methods in dairy products). - In: Ünlütürk, A., Turantaş, F. (eds.) G1da Mikrobiyolojisi (Food Microbiology), p: 287-306 3. Bask1, Metesan Basım Matbaacılık, Bornova-IZZMIR.

[40] WHO. (2012): World Health Organization, General information related to microbiological risks in food. - $\quad$ http://www.who.int/foodsafety/micro/general/ en/index.html Accessed on 19.07.12.

[41] Yücel, N., Anıl, Y. (2011): Çiğ süt ve peynir örneklerinden Staphylococcus aureus ve koagülaz negatif staflokokların identifkasyonu ve antibiyotik duyarlılığı (Identification and antimicrobial susceptibility of Staphylococcus aureus and coagulase negative Staphylococci isolated from raw milk and cheese samples). - Türk Hijyen ve Deneysel Biyoloji Dergisi 68(2): 73-78.

[42] Zhao, M. (2003): The design of haccp plan for a small-scale cheese plant. - The Graduate School, University of Wisconsin-Stout, Food and Nutritional Sciences, Master of Science Degree, 46p. 